\title{
Arap Dilinde Niyâbe
}

\section{Niyabah in Arabic Language}

\author{
Dr. Öğr. Üyesi Mustafa KARTAL ${ }^{1}$
}

1 Ondokuz Mayıs Üniversitesi/ Illahiyat Fakültesi/ Arap Dili ve Belagati
• mustafakartal2555gmail.com • ORCiD > 0000-0002-9619-1328

Makale Bilgisi / Article Information

Makale Türü / Article Types: Araştırma Makalesi / Research Article

Geliş Tarihi / Received: 15 Ekim / October 2021

Kabul Tarihi / Accepted: 3 Aralık / December 2021

Yil/Year: 2021 | SayI - Issue: 51 |Sayfa / Pages: 149-173

Atıf/Cite as: Kartal, M. “Arap Dilinde Niyâbe - Niyabah in Arabic Language”. Ondokuz Mayıs Üniversitesi Illahiyat Fakültesi Dergisi- Ondokuz Mayıs University Review of the Faculty of Divinity 51, Aralık 2021: 149-173. https://doi.org/10.17120/ omuifd.1009996

İntihal /Plagiarism: Bu makale, en az iki hakem tarafından incelendi ve intihal içermediği teyit edildi. / This article has been reviewed by at least two referees and scanned via a plagiarism software. http://dergipark.gov.tr/omuifd

Copyright @ Published by Ondokuz Mayıs Üniversitesi, İlahiyat Fakültesi - Ondokuz Mayıs University, Faculty of Divinity, Samsun, Turkey. All rights reserved. 


\section{ARAP DILINDE NIYÂBE}

\section{ÖZ:}

Bu makalede Arap dilinde niyâbe olgusu ele alınmaktadır. Kısaca, belli şartları taşımak kaydıyla bir öğenin başka bir öğe yerine kullanılması şeklinde tarif edilen ve bir nahiv 1stılahı olarak kullanımı oldukça geç dönemlerde başlayan niyâbe olgusunu açıklamak üzere nahiv ilminin teşekkül döneminde kullanılan sstılahlardan ve sonraki dönemlerde yapılan tanımlardan yola çıkarak niyâbe olgusunun ne olduğu ortaya konmaya çalışılmaktadır. Bunu yaparken gerek cümle ve gerekse írâb alameti düzeyinde niyâbe olgusunun dil ve gramer kitaplarındaki meşhur örnekleminden istifade edilmektedir. Son olarak bu olgunun varlık sebebine, dil ve gramer bakımından işgal ettiği konumuna işaret edilip, dilin gramatik bütünlüğüne ve anlam zenginliğine katkıları ortaya konmaya çalışılmaktadır.

Anahtar Kelimeler: Arap Dili ve Belagati, Niyâbe, Nahiv, İ'râb Alâmetleri

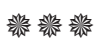

\section{NIYABAH IN ARABIC LANGUAGE}

\section{ABSTRACT:}

In this article, we discussed the phenomenon of Niyabah in the Arabic language. Niyabah is briefly described as the use of a phenomenon instead of another one, provided that it carries certain conditions. The phenomenon of Niyabah, which started to be used as a syntax term in a relatively late period, has been discussed in our study based on the terms used in the formation period of syntax and the definitions made in later periods. In this way, the phenomenon of Niyabah has been analyzed with various examples at the level of words, sentences, and i'rab signs, and its importance, function, and usage areas in terms of the Arabic language have been pointed out.

Keywords: Arabic Language and Rhetoric, Niyabah, Syntax, I'rab Signs 


\section{GíRiş}

Niyâbe (النيابة) kelimesi sözlükte -in yerine geçmek, yerini almak, temsil etmek, vekalet etmek gibi anlamlara sahip, sülâsi نابَ - نيُُوب - نَوَبًا ونِيابَنَ fiilinin mastarıdır. فَاَمَ مَقَامِي (falan kişi yerime geçti) şeklinde bir anlama sahiptir. ${ }^{[1]}$ Niyâbe kavramı bir nahiv ıstılahı olarak oldukça geç bir dönemde kullanılmaya başlanmıştır. Nahvî bir ıstılah olarak onu ilk kullanan kişi Zeccâcî (ö. 337/949) olsa gerektir. ${ }^{[2]}$ Ebû Hayyân (ö. 745/1344), niyâbenin en bariz örneklerinden birisi olan, nâib-i fâil kavramını ilk kullanan kişinin İbn Mâlik (ö. 672/1274) olduğunu ${ }^{[3]}$ ifade etmektedir. ${ }^{[4]}$ Geç dönemde 1stılahi bir hüviyet kazanmış olması sebebiyle niyâbenin ne olduğunu, Arap dilindeki yer ve konumunu tam olarak tespit edebilmek amacıyla bu dilin kurallarını yazıya geçiren ilk dönem dilcilerin onu ifade etmek

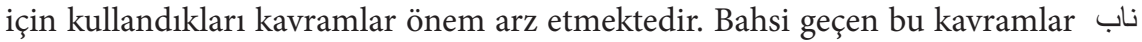
عنه، سد مسده، قام مقامه، حل محله، أجري مجر اه، وضع موضع كذا، وقع موقعه، أتى خلفا عنه genel olarak "yerine geçmek" anlamına gelen ifadelerdir.

Bir dilsel ıstılâhı ilk kez kullanan kişi için düşünüldügüünde, dile dair bir olguyu ifade etmek üzere kullandığı sstılahtan amaç ilk anda yalnızca o olguyu açıllamaktır. Örneğin niyâbe olgusunu ifade etmek üzere yukarıda değinildiği gibi pek çok dil âlimi farklı ıstılahlar kullanmışlardır. Bu âlimlerin öncelikleri kuşkusuz bir ıstılah türetmek değildi, önlerinde bulunan dil olgusunu açıklamaktı. Dolayısıyla her birinin aynı amaçla kullandığı ıstılah çok değerlidir. Ancak bir ıstılahın ve bu ıstılaha yüklenen anlamların kemâle ermesi pek çok âlimin katkısıyla uzun zaman içerisinde gerçekleşmektedir. Söz gelimi yukarıda verilen ifadelerin hemen hepsinin ortak paydası, "bir öğenin başka bir öğe yerine kullanılması" anlamını içermeleridir. Ancak Arap dilinde bir öğenin bir başka öğe yerine kullanılması şeklinde açıklanabilecek tek öğe niyâbe değildir, benzer başka dil olguları da vardır. Bu anlamda İbn Fâris'in (ö. 395/1004) "bir kelimeyi başka bir kelimenin yerine koymaktır” şeklinde tanımladığı ta 'vîzi 'Arabın şanındandır' şeklinde nitelendirip ardından verdiği çok sayıda örneğin aslında ta'vîzin değil niyâbenin örnekleri olmasi ${ }^{[5]}$ ıstılahların zamanla ayrıldıklarının en güzel örneklerinden birisidir. Dolayısıyla niyâbe olgusunun tam olarak anlaşılabilmesi için mana veya amel bakımından ona benzeyen veya onunla ortak bazı özelliklere sahip diğer ıstılahlarla farkının ortaya

[1] Muhammmed b. Mukrim Ebu'l-Fâzıl İbn Manzûr, Lisânu'l-'Arab (Beyrut: Dâru Sâdir, 1993), 1/774; Ebü’l-Feyz Muhammed Murtaza el-Huseynî ez-Zebîdî, Tâcü'l-'arûs min cevâhiri'l-kâmûs (Kuveyt: Matba'atu Hukûmeti'l-Kuveyt, 1977), 4/ 315.

[2] Ebu'l-Kâsım Abdurrahman b. İshak Ez-Zeccâcî, el-îzâh fî 'ileli'n-nahv (Beyrut: Dâru'n-Nefâis, 1979), 116; Mecid Nevd eş-Şemrî, "en-Niyâbe vemâ yudâri'uhâ minel'l-mustalehâti'n-nahviyye", Mecelletü'l-Feth 2/27 (2006), 22.

[3] Ebû Abdullah Cemaleddin Muhammed b. Abdullah Ibn Malik et-Tâî, Şerhu't-teshîl (Gîze: Hicr, 1990), 2/124.

[4] Ebu Hayyân el-Endelûsî, Irtişâfu'd-darb min Lisâni'l-Arab (Kahire: Matbaatu'l-Hânci, 1998), 3/1325.

[5] Ebü'l-Hüseyn Ahmed b. Fâris b. Zekeriyyâ ibn Fâris, es-Sâhibî fî fıkhi'l-luğa ve süneni'l-'Arab fî kelâmihâ (Beyrut: Dâru'l-Kütübi'l-'Illmiyye, 1997), 179. 
konması gerekir. Niyâbeye benzeyen diğer bazı olgular ta'vîz ('ivaz), bedel, tazmîn, muâkabe ve muşâbehe gibi dil olgularıdır. Burada niyâbenin ıstılahi anlamları verildikten sonra onun sınırlarını çizebilmek amacıyla bu kavramlara da çok kısa değinilecektir.

Bir nahiv ıstılâhı olarak niyâbe kavramını açıklamak üzere birkaç tanım yapılmıştır. Necib el-Lubdî, Mu'cemu'l-mustalehâti'n-nahviyye ve's-sarfiyye adlı eserinde niyâbeyi 'bir şeyi başka bir şeyin yerine koymak demektir' şeklinde tanımlamakta ve şu şekilde örneklendirmektedir: Hazfedildiği durumda fâilin yerini, bir mef' $\hat{u}$ lün bihin, zarfın, câr mecrûrun ya da mastarın almasıdır. Aynı şekilde bir mastarın, emir fiil yerine kullanılmasıdır. ${ }^{[6]}$

Modern araştırmacılardan Mecid Navd Ubeyd'in tanımına göre niyâbe; 'nâib olan lafzın anlam ya da fonksiyon bakımından yahut cümledeki görev veya konum açısından içinde bulunduğu durumu hak etmeme halini' ifade eder. ${ }^{[7]}$

Nihad Felih Hasan ise niyâbeyi, ister anlam ister görev düzeyinde olsun isterse írâb veya bina düzleminde olsun bir lafzın, luğavî olarak asaleten kendisine ait olmayan bir konumda gelip aslın yerini alması ve onun bütün şartlarını taşıması olarak tanımlar. ${ }^{[8]}$

Abdulazim eş-Şâir'in "bir lafzın asalet bakımından kendisine ait olmayan bir konumda olması ve amel, i'rab durumu, ifade ve cümledeki görev bakımından yerine geçtiği öğenin yerini almasıdır” şeklindeki niyâbe tanımı üstteki son iki tanıma kaynaklık etmiştir. ${ }^{\text {[9] }}$

Niyâbe için yapılan bu tanımları kusurlu ve yetersiz olarak niteleyip eleştiren Abdullah Salih, "Arap dilinde kullanımı asıl olarak bilinen söz dizimi kuralları gereğince cümlede yer alması beklenen (yer aldığı kabul edilen) unsurlardan birinin düşürülüp onun yerini başka bir unsurun alması ve bu yeni unsurun düşürülen unsurun özelliklerinin bir kısmını (hepsini değil çünkü onun kendisi değil) taş1ması" ${ }^{10]}$ şeklinde bir tanım getirmiştir. Bu tanımı irdelediğimizde diğerlerinden farklı olarak ilk göze çarpan şey hazif meselesidir. Her ne kadar bir öğenin bir başka öğenin yerini alması ifadesi zihinde hazfi canlandırsa da önemine binaen tanımda yer verilmesi daha makul gözükmektedir. Hazif gerçekleştikten sonra baş-

[6] Muhammed Semîr Necib el-Lubdî, Mu'cemu'l-mustalehâti'n-nahviyye ve’s-sarfiyye (Beyrut: Muessesetu'r-Risâle, 1985), 233.

[7] Abdullah Salih Amr Bâbe'ir, Zâhiratu'n-niyâbe fi'l-'Arabiyye (Yemen: Dâru Hadramevt, 2010), 28; Eymen Mubarek Ramazan eş-Şemâyile, En-Niyâbetu fi'n-nahvi'l-Arabî (Yüksek Lisans Tezi, Ürdün Üniversitesi, Lisansüstü Çalışmalar Enstitüsü, 2011), 10.

[8] Bâbe'ir, Zâhiratu'n-niyâbe fi'l-'Arabiyye, 28; eş-Şemâyile, En-Niyâbetu fi'n-nahvi'l-Arabî, 10.

[9] Bâbe'ir, Zâhiratu'n-niyâbe fi'l-'Arabiyye, 29.

[10] Bâbe'ir, Zâhiratu'n-niyâbe fi'l-'Arabiyye, 32. 
ka bir unsur gelerek mahzuf öğeye nâib olacaktır. Bu durumda, yerine başka bir şey getirilmeksizin hazfin olduğu bir cümlede ya da herhangi bir hazif olmaksızın cümlede bulunan fazla bir öğe sebebiyle niyâbe söz konusu olmamaktadır. Niyâbenin gerçekleşebilmesi için ikinci olarak, mahzufun yerine gelen öğenin, onun yerini işgal ediyor olması gerekir. Aslında cümleden düşürülen öğe, asıl unsurlardan birisi olduğu için o düşünce cümlede bir eksiklik meydana gelmekte ve yeni gelen öğe onun yerini işgal ederek bu boşluğu doldurmaktadır. Dilcilerin niyâbenin bulunduğu öğeleri anlatırken قام مقامه، حلَّ محله، وقع موقو sebepledir. İbn Serrâc (ö. 316/929) nâib-i fâil konusunu işlerken cümleden düşen ve onun yerine gelen unsurların bu özelliklerini şöyle anlatmaktadır: "Fiil cümlesi fâilsiz tamam olamayacağı için (fâil asıl öğelerden olduğu için) fâili zikretmediğin durumda mef' ûl, merfû konuma gelip onun yerini alır. Ancak mef' ûlün, fâil konumuna gelip ref edilmesi ancak fâilin hazfi durumunda mümkündür. Aksi durumda mef 'ûl mansup olmak zorundadır. ${ }^{[11]}$ Tanımlarda ortaya çıkan diğer bir husus da nâib unsurun, amel, i’râb ve delâlet bakımından yerine geldiği öğenin özelliklerini üstlenmesidir. Nihad Felih'in tanımında yer alan 'onun bütün şartlarını taşıması' ibaresiyle kastı da bu özellikler olmalıdır. Zira mahzuf öğeya ait şart veya şartlar söz konusu değildir. Yine nâib öğe, yerine geçtiği öğenin bizzat kendisi olmadığı için sonuçta onun tüm özelliklerine haiz olmayacak, bazı özelliklerini taşımayacaktır. Örneğin menûb 'anhın en çok özelliğini taşıyan nâib türü olan nâib-i fâil bile mef '̂̂liyetten yükseldiği bu yeni makamında tam bir fâil gibi olmamakta anlam bakımından da olsa hala bir mef'ûllük taşımaktadır. Bazı dilcilerin nâib-i fâili ş المفعول الذي لم يسمَّ فاعله ait tanımın kusurlu yanı ise niyâbeyi yalnızca cümle terkiplerinde gerçekleşen bir olgu olarak sunmasıdır. Bu tanıma göre bir harfin başka bir harfe veya harekeye nâib olması ya da harekelerin birbiri yerine geçmesi niyâbe kapsamı içerisine girmemektedir. İ́râb alametlerinin birbiri yerine nâib olması konusunda bu hususa değinilecektir.

\section{1- Niyâbeye Benzer Diğer Dil Olguları}

Daha önce bahsedildiği üzere kadim dilciler niyâbe terimini kullanmamakla birlikte ortak paydası 'bir öğenin başka bir öğenin yerine kullanılması' olan çeşitli terimler kullanmışlardır. Niyâbe olgusunun özü bu olmakla birlikte Arap dilinde bir şeyin başka bir şeyin yerini alması şeklinde tezahür eden başka dil olguları da vardır. Niyâbenin genel çerçevesinin tam olarak çizilebilmesi için bu olgulara ve niyâbenin bunlardan farklı yanlarına dikkat çekmek gerekmektedir. Bu başlık altında bu dil olgularına değinilecektir.

[11] Ebû Bekr Muhammed b. Seri b. Sehl el-Bağdadi ỉbnü's-Serrac, el-Usûl fi'n-nahv (Beyrut: Müessesetü'r-Risâle, t.y.), 1/77.

[12] Bu konuda ayrıntılı bilgi için bkz. Bâbe'ir, Zâhiratu'n-niyâbe fi'l-'Arabiyye, 32-52. 
'Bedel' ve 'ta vîz' bahsi geçen dil olgularındandır. Lisânu'l-Arab'da bedel, bir şeyin başka bir şeyin yerine konması şeklinde tarif edilip kasem ifade eden و الله ifadesinde vâv harfinin tâ harfine ibdâl edilip تالله şeklinde kullanımı ile örneklendirir. ${ }^{[13]}$ İbn Yaîş (ö. 643/1245) ise bedeli zaruret ya da uygunluk (istihsân) sebebiyle bir harfin başka bir harfin yerine konması şeklinde tanımlamaktadır. ${ }^{[14]}$ Ta'vîzi ('1vaz) de aynı şekilde bir harfi başka bir harfin yerine ikame etmek şeklinde tanımlayan İbn Yaiş ikisi arasındaki farklılığı ' 'vazda gelen harfin düşen harfin olduğu yere değil de başka bir yere gelmesi şeklinde açıklamakta ve bunu عدة velimeleriyle örneklendirmektedir. ${ }^{[15]}$ Zira bu iki kelimenin başındaki vâv harfleri düşmüş, '1vaz olarak gelen tâ-i merbûta ise kelimenin başına değil sonuna eklenmiştir. 'Ivaz için modern dönemde yapılan bir tanım da şu şekildedir: 'Ivaz; müfred veya mürekkeb bir kelimenin veya cümlenin bazı unsurlarının hazfedilip yerine bir harfin getirilmesidir, ıvaz olarak gelen harfin mu'avvazın yerine gelmesi zaruri değildir, oraya da gelebilir başka bir yere de. 'Ivaz, زَبَنَِّ örneğinde olduğu gibi kelimede; örneklerindeki tenvinin mahzuf muzâfun ileyhin 'ivazı olması gibi terkipte veya حينئذ in sonundaki tenvin gibi cümleden 'vaz olabilir. ${ }^{[16]}$ Bedel ile '1vaz arasındaki farklılıklardan birisi, bazı istisna durumları hariç olmak üzere bedel kıyâsî iken 'ivaz daha çok semâîdir. ${ }^{[17]}$ Örneğin يا له ifadesinde nidanın hazfedilip ona 'ivaz olarak sonuna mîm eklenmesiyle ulaşılan اللهم lafzından yola çıkarak burada olanın benzer şekilde başka kelimelere de uyarlanabilmesi söz konusu değildir. Ancak babına aktarımında uğradığı değişiklik kıyâsî olup misâlî vâvîlerin hepsi için geçerlidir. Her iki kavramın niyâbe ile ortak yanı bir şeyin başka bir şeyin yerine ikame olmasıdır. Farklılıkları ise hazif ve yerine ikame, bedel ve 'vazda kelime üzerinde gerçekleşirken niyâbede cümlede veya cümlenin bir gereği olan i'râb alametlerinde gerçekleşmesidir. Yine bedel ve 'ivazda ikame edilen öğe mahzuf unsura ait herhangi bir özelliği taşımazken niyâbede onun bir kısım özelliklerini taşımaktadır.

Niyâbe ile nahiv ilmindeki bedelin farklılığına da değinmek gerekir. Nahivdeki bedelden amaç önceki hükmü (mübdel minh) pekiştirmek, ona dair açıklama getirerek yanlış anlaşılmanın öne geçmektir. Niyâbede ise nâib, menûb 'anhin yerine gelir, onun mahallini işgal eder ve onun hükmünü alır. Buradaki önemli bir incelik nâibin bu hükmü bir tâbî olduğu için değil bizzat mahalli işgal ettiği için almasıdır. Bedel ise tam tersine mübdel minhin hükmünü onun bir tâbîi olarak almaktadır. Böylece nâib içerisinde bulunduğu cümlenin temel öğelerinden birisi iken bedel böyle değildir. Aynı şekilde bedel ile mübdel minh aynı cümlede yer alabilirken,

[13] ỉbn Manzûr, Lisânu'l-'Arab, 1/231.

[14] Ali b. Ya'îş İbn Ya'îş, Muvaffakuddin Ya'iş b. Ali, Şerhu'l-mufassal (Mısır: Idâretü't-Tıbâ'ati'l-Münîriyye, t.y.), $10 / 7$.

[15] İbn Ya'îş, Şerhu'l-mufassal, 10/7.

[16] Bâbe'ir, Zâhiratu'n-niyâbe fi'l-'Arabiyye, 137.

[17] Abbas Hasan, en-Nahvu'l-vâfî (Kahire: Dâru'l-Meârif, 4/759. 
nâib yalnızca menûb 'anhin hazfi durumunda ortaya çıkar. ${ }^{[18]}$

Niyâbeye benzer şekilde tanımlanan bir diğer olgu bir kelimenin başka bir ke-

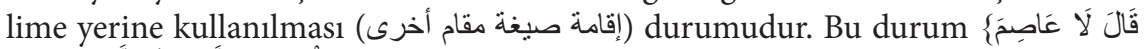

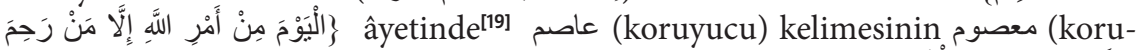

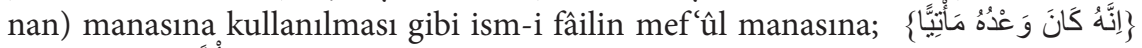

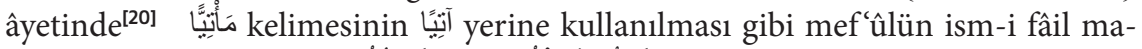

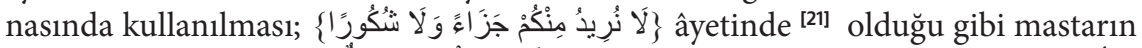

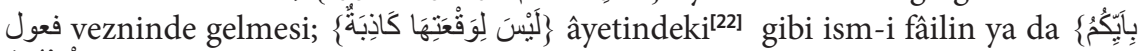

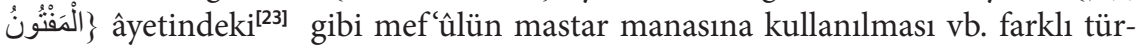
lerde olabilir. ${ }^{[24]}$ Bir öğenin başka bir öğe yerine kullanılması yönüyle niyâbeye benzeyen bu olgu Kur'ân-1 Kerim'in ve Arap dilinin hitap üsluplarından birisidir.

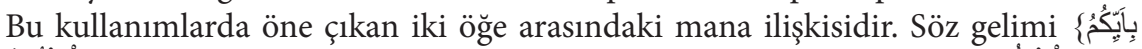

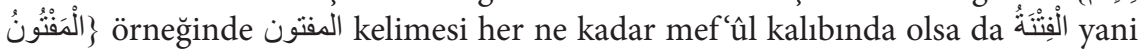
mastar manasındadır. Niyâbede ise öne çıkan husus mana aktarımından ziyâde nahiv ve i’rab bakımından bir öğenin bir başka öğenin yerini almasıdır. Mana açısından bakıldığında niyâbede, nâib öğe menûb 'anhın i’rab ve hüküm bakımından hükümlerini taşımakla birlikte onun manasına sahip olmadığı durumlar da vardır. Söz gelimi bir mef'ûl, nâibi fâil konumuna geldiğinde de aslında mef'ûliyye manasını korumakta, ancak i’rab ve hüküm bakımından fâilin özelliklerine sahip olmaktadir.

Görüldüğü üzere niyâbe olgusu, benzerlerinden kendine ait bazı özellikleriyle ayrılmaktadır. Özetle niyâbe olgusundaki temel özellik bir öğenin hazfedilip yerine başka bir şeyin gelip onun yerini işgal etmesi ve ona ait bazı özellikleri bünyesinde barındırmasıdır. Konunun daha iyi anlaşılması için cümle ve i'râb alameti düzeyinde niyâbe ile açıklanan bazı durumlar ele alınıp örnek olarak sunulacaktır.

\section{2- Nâib-i Fâil}

Nâib-i fâil ilk dönem dil kitaplarında genellikle لم يُسَََّ فَاعِلُه (fâili zikredilmeyen) şeklinde isimlendirilir. Bu şekilde isimlendirilme sebebi fiilin gerçek fâilinin zikredilmemesidir. Müberred bunu (ö. 286/900) fâilin yerini alan öğeyi öne çıarta-

[18] Bu konuda ayrıntılı bilgi için bkz. eş-Şemrî, "en-Niyâbe”, 24.

[19] Hûd 11/43.

[20] Meryem 19/61.

[21] el-insan 76/9.

[22] el-Vâkı 56/2.

[23] el-Kalem 68/6.

[24] Imâm Bedreddin Muhammed b. Abdillah ez-Zerkeşî, el-Burhân fî 'ulûmi'l-Kur'ân (Kahire: Mektebetü Dari't-Turâs, 1984), 2/285-292. 
rak الََْفْوُل الَّذِي لَا يذكر فَاعله (fâili zikredilmeyen mef'ûl) şeklinde isimlendirmiştir. ${ }^{[25]}$ Ancak nâib-i fail kavramı fâilin yerine geçen öğenin her zaman mef 'ûl olmadığı düşünüldüğünde daha kapsayıcı bir isimlendirme olarak karşımıza çıkmaktadır.

Bir öğenin fâile nâib olabilmesi için ilk aşama gerçek fâilin hazfedilmesidir. Fâilin hazfi veya zikredilmemesi pek çok amaç için olabilir. Zikrini gerektiren bir nedenin olmaması, tazim veya tahkir, muhatabın fâili zaten biliyor olması, zikrinden duyulan endişe veya korku ve sözü söyleyenin fâilin kim olduğunu bilmiyor oluşu bu sebeplerdendir. ${ }^{[26]}$ İkinci aşama fâilin hazfiyle oluşan boşluğu bir başka öğenin doldurmasıdır. Zira fâilsiz bir fiil olamayacağı için onun hazfi durumunda zorunlu olarak bir başka öğe onun yerini alır. Üçüncü ve son aşama ise fâilin yerine geçen ve nâib-i fâil diye isimlendirilen bu öğenin, fiilin kendisine isnâdı sebebiyle yerini işgal ettiği fâilin i'râbını alması, yapısına göre lafzen, takdîren veya mahallen merfû olmasidir.

Fiilin hazfedildiği cümlede hangi öğelerin nâib-i fâil konumuna geçeceği ve hangilerinin geçemeyeceği konusu dilcilerin uzun uzun açılamalar yaptıkları ve zaman zaman da görüş ayrılıklarına düştükleri bir konudur. Ancak fâilin yerine geçecek öğenin birinci sırada mef 'ûlün bih olacağı çoğunun ortak görüşüdür. ${ }^{[27]}$ Bu görüşü paylaşan İbnü'l-Enbârî, (ö. 577/1181) aralarında cümle içerisinde zıtlık bulunan mef'ûlün fâilin yerini nasıl alabileceği sorusuna cevap arayarak durumu mantıksal bir zemine oturtmaya çalışır. Ona göre bu durumun garipsenecek bir yanı yoktur. Zira mef'ûlün fâil konumunda olması Arap dilinde benzeri olmayan

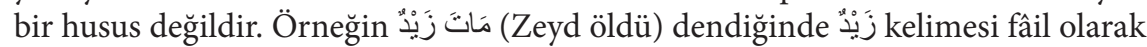
gösterilmesine rağmen aslında mef' ûl manasındadır. Çünkü ölme eylemini gerçekleştiren fâilin kendisi değildir. Bu örnekte mef ' ûl nasıl fâil konumunu almışsa meçhul yapılarda da benzer durum söz konusudur. ${ }^{[28]}$

Mef'ûlün bihin fâile nâib olduğu cümlede fiil eğer tek mef' ûl alan bir fiilse, artık mef' ûl almayacak, iki mef' ûle müteaddî ise tek mef' ûl alacaktır. İki mef' ûl alan bir fiilde, hangisinin nâibi fail konumuna yükseleceğine dair İbnü’l-Enbârî anlamın bozulmaması durumunda her ikisinin de nîb-i fâil olabileceğini ama anlam bozuluyorsa ilkinin olacağını ifade etmektedir. örneğin أعطيتُ زيدًا در همًا (Zeyd’e bir dirhem verdim) cümlesi, أعطِيَ زيدٌ درهمًا (Zeyd’e bir dirhem verildi) şeklinde olabileceği gibi أعطِيَ درهمُ زيدًا (bir dirhem Zeyd’e verildi) şeklinde de meçhul ola-

[25] Ebu'l-Abbâs Muhammed b. Yezîd el-Müberred, el-Muktedab (Kahire: Lecnetü Ihyâ-i Türâsi'l-Islâmi, 1994), $4 / 50$.

[26] Ebu'l-Bekâ Abdullah b. Huseyn el-Ukberî, el-Lübâb fî 'ileli'l-binâ ve'l-i'râb (Beyrut: Dârü'l-Fikri'l-Muâsır, 1995), 1/157; Bu konuda ayrıntılı bilgi ve örnekler için bkz. Fazıl Salih es-Samerrâî, Me'âni'n-nahv (Kahire: Şeriketu'l-'Atik lisınâ'ati'l-Kitâb, 2003), 2/62-68.

[27] Celâleddin Abdurrahman b. Ebî Bekr es-Suyûtî, Hem'u't-hevâmi' fî şerh-i cem'i-l'cevâmî' (Beyrut: Daru'l-Kütübi'l-Ilmiyye, 1998), 1/518.

[28] Ebû'l-Berekât el-Enbârî, Esrâru'l-'Arabiyye (Kuveyt: Vuzâretu'l-Evkâf ve'ş-Şuûni'l-İlâmiyye, 2015$), 70$. 
bilir. Çünkü her iki durumda da bir anlam karmaşası söz konusu değildir. Ancak aynı şey أعطيثُ زيدًا غلانًا (Zeyd’e bir köle verdim) cümlesi için geçerli değildir. Zira burada her iki mef 'ûl de mana olarak "alma" eylemini gerçekleștirme imkânına sahiptir. Dolayısıyla burada ilk mef ûlün bırakılıp أعطِي غلامٌ زيدًا şeklinde ikinci mef 'ûlün nâib-i fâil yapılması caiz değildir. ${ }^{[29]}$ Aynı şekilde eğer iki mef' ûl alan fiil zanne ve kardeşlerinden ise yani aslı mübteda haber olan iki mef '̂ul alan bir fiil ise bu durumda yalnızca birinci mef 'ûl nâibi fâil konumuna geçebilir. Zira ikincisi özünde haberdir, haber ise mübtedaya isnâd edilmiştir, aynı zamanda fiile de isnâd edilemez. ${ }^{[30]}$

Üç mef' ûl alan fiiller de meçhul yapıldıklarında iki mef' ûl alır hale gelir. Bu fiiller için de fâiliyet manasını taşıyor olması sebebiyle ilk mef 'ûlün nâib-i fâil yapılması en uygun olanıdır

Meçhul yapıda fiilin yapısının değişme sebebi ise ardından gelen öğenin fail mi yoksa fail konumuna yükseltilmiş mef' ûl mü olduğunu göstermek içindir. İbnü’l-Enbârî meçhul yapıda fiilin damme ile başlatılmasını düşen öğenin fâil olduğunu belirtmek üzere onun konumuna işaretle ilk harfin damme olduğunu, ikinci harfin kesra yapılmasının ise yeni oluşan fiilin diğer kalıplara benzememesi için olduğunu öne sürer. ${ }^{[31]}$ Ukberî (ö. 616/1219) ise ilk harfin damme yapılmasını bu sebebe bağlamayı zayıf bir görüş olarak nitelendirip meçhul sîgalardaki hareke düzeninin, isim veya fiillerde bir benzerinin olmaması sebebiyle bu şekilde yapıldığı görüşünü savunur. ${ }^{[32]}$

Mef 'ûlün bihin bulunmadığı bir cümlede, zaman zarfı, mekân zarfı, mastar ve câr mecrûr nâibi fâil konumuna yükselebilir. Bir cümlede bunlardan birkaçı aynı anda yer alıyorsa dilcilerin çoğunluğuna göre orada muhayyerlik vardır. İstenilen birisi nâib-i fâil yapılabilir. ${ }^{[33]}$ Ancak bu durum cümlede mef ' ûlün bihin olmadığ durum içindir. Zira eğer cümlede mef 'ûlün bih varsa fâilin yerini alacak öğe odur. Ukberî, ona bu önceliği veren sebepleri sıraladıktan sonra Kûfeli dilcilerin aynı görüşü paylaşmadığını belirtir. ${ }^{[34]}$

Burada dikkat çekilmesi gereken husus nelerin nâib-i fâil olacağından ziyade nelerin olamayacağı ve niçin olmayacağı meselesidir. Çünkü niyâbede öne çıkan şeylerden birisi nâibin, yerine geçtiği öğenin özelliklerini taşıması gerekliliğidir. Fâilin özelliklerini taşıyamayan öğeler nâib-i fâil olamazlar. Örneğin bir fâil açık

[29] İbnü's-Serrac, el-Usûl fi'n-nahv, 1/79; el-Enbârî, Esrâru'l-'Arabiyye, 71.

[30] es-Samerrâî, Me'âni'n-nahv, 2/70.

[31] el-Enbârî, Esrâru't-'Arabiyye, 74.

[32] el-Ukberî, el-Lübâb, 1/158.

[33] el-Enbârî, Esrâru'l-'Arabiyye, 75; es-Suyûtî, Hem'u'l-hevâmi', 1/523.

[34] el-Ukberî, el-Lübâb, 1/159. 
veya gizli, marife veya nekra olabilirken hâl konumundaki bir öğe ise yalnızca nekra olabilir, marife olamaz. Aynı şekilde haller başka bir öğeye (sahibu'l-hâle) isnâd edilmiş olmaları yönüyle tıpkı haber gibidirler. İkinci bir isnâd mümkün olmadığı için fâil konumuna geçemezler. Benzer özelliklerinden dolayı, temyiz, mef '̂ulün leh, müstesna gibi öğeler gerek yapı bakımından fâillik konumundan farklılıkları sebebiyle gerekse konum değiştirmeleri halinde ortaya çıkacak anlam kaybı sebebiyle nâib-i fâil olamazlar. ${ }^{[35]}$ Özetle niyâbede esas olan nâibin, menüb 'anhın hükmünü taşıması ve onun görevlerini yüklenebilmesidir. Bu potansiyele sahip olmayan bir öğenin nâib olması söz konusu değildir.

Nâib-i fâilin fâil konumuna yükselip ref edilmesi kıyasa göredir. Buna göre nâib-i fâil, yerini aldığı öğe olan fâile kıyasla merfû olmaktadır. Bu kıyasta fâil, asıl; hüküm, ref konumda olma; illet ise fiile isnâddır. ${ }^{[36]}$ Nâib’i fâil olarak fâil konumuna yükseltilen öğe cümle içerisinde artık fâilin yerini işgal ettiği için onun özelliklerini taşımak durumunda olacaktır. Söz gelimi mef 'ûl konumunda olduğunda mansup iken artık merfû olacak, cümlenin tamamlayıcı unsurlarından birisi iken yeni konumunda asıl öğelerinden birisi olacak, öncesinde fiilinin önüne geçmesi mümkünken artık geçemeyecek, fiil ile müzekkerlik müenneslik bakımından herhangi bir ilgisi yok iken artık fiil ona göre şekillenecektir.

\section{3- Nâib-i Mef'ûli Mutlak}

Mef'ûlün mutlak, âmilini tekit eden, onun türünü veya sayısını gösteren man-

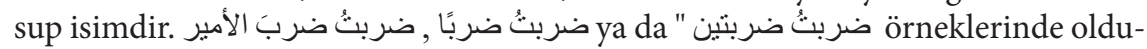
ğu gibi. Mef 'ûlün mutlak çoğunlukla fiilin mastarıdır.

Mef'ûlün mutlak şeklinde isimlendirilme sebebi, fâilin gerçek mef 'ûlü olması, harfi cer vb. herhangi bir bağlantıya ihtiyaç duymaksızın ona doğrudan bağlanmasıdır. Nitekim diğer mef 'ûl türleri bu şekilde doğrudan fâilin mef 'ûlü değillerdir. Onların mef' $\hat{u} l$ diye isimlendirilmeleri, fiille olan bağlantıları, onun yerini veya zamanını bildirmeleri sebebiyledir. ${ }^{[37]}$

İlk dönem gramer kitaplarında mef'ûlün mutlak kavramı yerine daha çok mastar kelimesi kullanılır. المصدر المنصوب ya da المنصوب على المصدريّة gibi ifadelerle anılır. Ancak mastar, mef 'ûlün mutlaka göre çok daha umumi bir kavramdır. İki kavram arasındaki fark, canlı kavramı ile insan kavramı arasındaki farka benzetilir. İnsan bir canlı olmakla beraber, bütün canlılar insan değildir. Aynı şekilde mastar bir cümlede mef'ûlün mutlak olabileceği gibi, fâil, mef' ûlün bih, mef' ûlün leh

[35] el-Ukberî, el-Lübâb, 1/161-163.

[36] Celâleddin Abdurrahman b. Ebî Bekr es-Suyûtî, el-iktirâh fî usûli'n-nahv (Dimaşk: Dâru’l-Beyrûtî, 2006), 181.

[37] Ebü'l-İrfan Muhammed b. Ali es-Sabban, Hâşiyetu's-Sabbân 'alâ Şerhi'l-Üşmûnî lielfiyyeti ibni Mâlik (Beyrut: Dâru'l-Kütübi'l-'ilmiyye, 1997), 2/161. 
gibi çok sayıda öğe olabilecekken mef 'ûlün mutlak sadece mastar olabilir. Nitekim bazı dilciler mef '̂ulün mutlakı doğrudan mastar olarak tanımlamışlardır. ${ }^{[38]}$

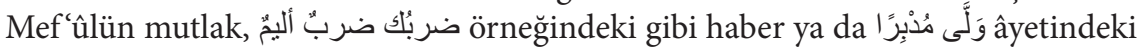

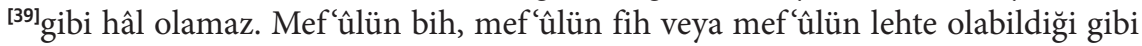
bir câr ile ya da mef 'ûlün me'ah gibi bir zarf ile de kayıtlanamaz. ${ }^{[40]}$ Yani sadece mastar olması bir kelimenin mef' ûlün mutlak olması için yeterli değildir.

Mef' ûlün mutlakta asıl olan mastar olmakla birlikte zaman zaman onun yerini bu mastara delalet eden başka öğeler alabilir. ${ }^{[4]}$ Yani mastara nâib olabilir ki bu başlık altında bunlar ele alınacaktır.

Tanımında da zikredildiği üzere mef' ûlün mutlakın âmilini tekid eden, onun türünü veya sayısını bildirenler şeklinde üç farklı türü vardır. Mef 'ûlün mutlakın özellikleri hangi tür için olduğuna göre değişiklik gösterebilmektedir.

Yalnızca tekid için olan mef'ûlün mutlak, amel etmez ${ }^{[42]}$, tesniye veya cemi yapılmaz. Zira başka bir şeyle kayıtlanmamış mastar cins manası ifade eder hem müfrede hem cemiye delalet eder. Âmili (fiili), hazfedilmez ${ }^{[43]}$ ve âmilinin öncesinde gelmez. Diğer iki tür mef' ûlün mutlak da çoğunlukla amel etmez, ancak bunlar tesniye veya cemi yapılabilir ve âmilinin önüne geçebilirler.

Nelerin niyâbeten mef 'ûlün mutlak olabileceğine geçmeden önce şunu özellikle vurgulamak lazım ki niyâbeden söz edebilmek için bir kere asıl öğenin yani fiilin mastarının hazfedilmesi gerekir. Hazif gerçekleştikten sonra ancak bir öğe gelip onun yerini alabilir. Burada mef' ûlün mutlakın hazfedilebilmesi için temel bir şart vardır ki o da mef '̂ulün mutlakın fiilin kendi mastarı olmasıdır. Mef '̂ulün mutlak konumundaki öğe fiil ile aynı kökten türeyen bir mastar veya eş anlamlı bir mastar ise bu durumda onun hazfedilip yerine başka bir öğenin geçmesi söz konusu değildir. Zira mesela bir كلّ kelimesi gelmişse nâib-i mef '̂uli mutlak olarak bunun için söylenebilecek tek söz cümledeki asıl fiilin mastarına nâib olduğudur. Başka bir fiilin mastarı onun yerine geçemez. Mef '̂̂lün mutlaklar mansup oldukları için, mahzuf mastarın yerine nâib olarak gelen öğe de ona niyâbeten mansup olarak i'râb edilir. ${ }^{[4]}$

[38] İbn Ya'îş, Şerhu'l-mufassal, 1/109.

[39] en-Neml 27/10.

[40] Muhammed Muhyeddin Abdulhamid, Evdahu'l-mesâlik ilâ Elfiyyeti Ibn Mâlik (Beyrut: Menşûrâtu'l-Mektebeti'l-Asriyye, t.y.), 2/205-206

[41] es-Sabban, Hâşiyetu's-Sabbân, 2/159.

[42] Mahzuf fiilinin nâibi olması durumu dışında.

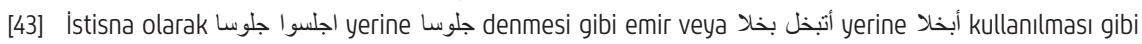
bazı talebi istifhami cümlelerde âmili zorunlu olarak hazfedilir. Bu konuda ayrıntılı bilgi için bkz. Hasan, en-Nahvu'l-vâfî, 2/211.

[44] Hasan, en-Nahvu'l-vâfî, 2/213. 
Fiilin mastarına niyâbeten mef 'ûlün mutlak olarak gelebilecek öğeler şunlardır:

- Mastarın eş anlamlısı; جلستُ جلوسا yerine جلستُ قعودا denmesi gibi.

- Özel isim olmamak şartıyla ism-i mastar ${ }^{[45]}$ örneğindeki gibi.

- Mahzuf mastara dönen bir zamir veya ism-i işaret. Örneğin samimiyetten

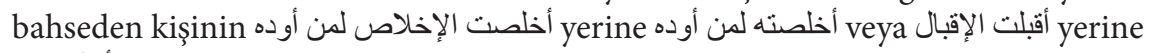
demesi gibi.

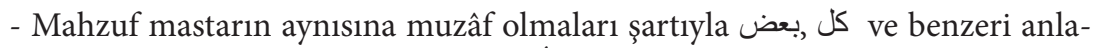
ma sahip kelimeler. Örneğin كلّ kelimesi mef' ûlün

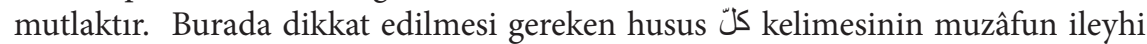
konumundaki الإنفاق kelimesi fiilin kendi mastarı olmakla birlikte mef'ûlün mutlak değildir. Bu cümlede كل kelimesi, hazfedilip yerine konumlandırıldığ إنفاق kelimesinin nâibidir.

- Mahzuf mastarın sıfatı. Örneğin تكلمت تكلمًا أحسن التكلم yerine تكلمت أحسن التكلم.

يدور عقرب الدقائق في الساعة ستين دورة Mahzuf mastara delalet eden sayı. Örneğin

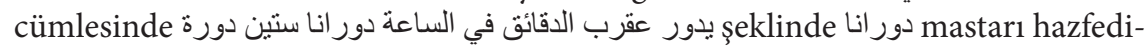
lip ستين sayısı onun nâibi olarak mef' ûlün mutlak konumundadır.

- Mahzuf mastarı eyleme dökmeye yarayan alet; سقيت العاطش كوبًا örneğinde fiilin mastarı olan السقي hazfedilmiş ve كوب kelimesi ona nâib olmuştur. Burada önemli olan mahzuf mastarın yerine geçen öğenin, o mastarın eyleme dökülmesine delalet eden bir alet ismi olmasıdır. Mezkur örnekte bulunan bardak kelimesi içmek-içirmek eylemi için normal şartlarda kullanılan bir alet olduğu için ona nâib olabilmiştir. Ama mesela دَّلْ (kova) kelimesi normalde su içmek için kullanılmayan bir eşya olduğu için سقي mastarına nâib olarak kullanılmaz.

- Mahzuf mastarın türlerinden birine delalet eden isim. Örneğin قعد الطفل القعد الطفل قعود القرفصاء dan dönüştürmedir. Burada القرفصاء kelimesi bağdaş kurma, çömelme anlamında oturma türlerinden birini karşıladığı için mahzuf mastara nâib olmuştur.

- Mahzuf mastarın heyetine/biçimine delalet eden lafız. فِعْعَّة kalıbı bu anlamı ifade eder. Örneğin مشى القط مِشية الأسد këmlesinde مِشية kelimesi mahzuf mastara nâib olarak mef'ûlün mutlaktır.

[45] manaya delâleti bakımından filin mastarı ile aynı olan ve iştikak yönüyle de onunla aynı kökten türemiş olan ama o fiile ait olmayan bir mastardır. Harf sayısı asıl mastardan daha azdır. 
Burada verilenlerin dişında mahzuf mastarın vaktine delalet eden lafız, mâ-i istifhâmiyye, mâ-i şartıyye gibi başka öğeler de vardır. ${ }^{[46]}$

Görüldüğü gibi fiilin kendi mastarı dışında mef '̂ulün mutlak konumunda olabilen öğeler mastarlar ve mastar olmayanlar olmak üzere iki grupta ele alınabilir. Bunlardan mastar olanların fiilin kendi mastarına niyâbeten mi yoksa doğrudan mı mef '̂ulün mutlak oldukları bir başka deyişle bir fiilin kendi mastarı dışında başka bir mastarı doğrudan mef 'ûlün mutlak olarak alıp alamayacağı hususu dilciler arasında ihtilaflı bir konudur. İkinci durumda yani bir fiilin kendi mastarı dışında başka bir mastarı doğrudan mef 'ûlün mutlak olarak alması durumunda niyâbe söz konusu olmamaktadır. Müberred ve Sîrâfînin (ö. 368/979) de içinde bulunduğu çoğunluk bu görüşü savunur. Sibeveyhi (ö. 180/796) ise bu tip cümlelerde uygun bir fiil takdir ederek, mef '̂́lün mutlak olan öğeyi ona bağlar. Örneğin

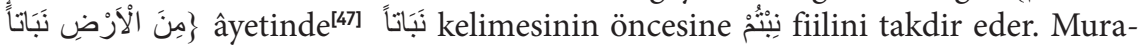
dif mastarın mef'ûlün mutlak olması hususunda da aynı fikri savunan Sibeveyhi

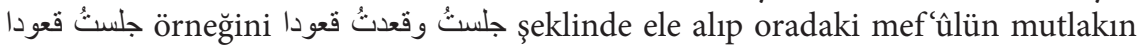
قعدتُ rı olan hazif-işgal eylemleri gerçekleşmediği için burada da niyâbeden söz etmek mümkün değildir. Her ne kadar dilciler bu konuyu mastara nâib olan öğeler başlı̆̆ 1 altında ele alsalar da görüldüğü üzere bu durum yalnızca haziften ibarettir. Çünkü dilcilerin getirdiği her iki açıklama; fiilin kendi mastarı yerine aynı kökten türemiş başka bir fiilin mastarını veya eş anlamlı bir başka fiilin mastarını doğrudan mef' ûlün mutlak olarak nasbetmesi ya da mansup öğenin öncesine kendi fiilinin takdir edilmesi durumlarının ikisi de niyâbe olmamaktadır. Bu konuda diğer bir görüş ise Mâzini’ye (ö. 249/863) ait olan görüştür. Onun ileri sürdüğüne göre جَلَمْنُ

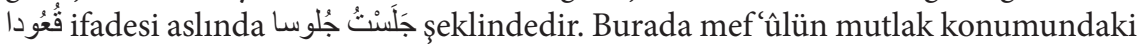
جلوسا kelimesi hazfedilip ona niyâbeten eş anlamlı bir mastar olan قعودا kelimi getirilmiştir. Diğer iki açıklamanın aksine durumu niyâbeye ile açıklayan bu görüş son dönemlerde meşhur olan görüştür. ${ }^{[49]}$

Mastarın hazfedilip ona nâib olarak başka bir öğenin getirilmesi bazı amaçlara binâen yapılır. Anlam genişliği sağlamak bunların en önemlilerindendir. Örneğin bir mastarın yerine sıfatının kullanılması ile, mastarın zikredilmesi durumunda ifade edemeyeceği belki hiç ihtimal dahilinde bile olmayacak yeni bir anlam ifade

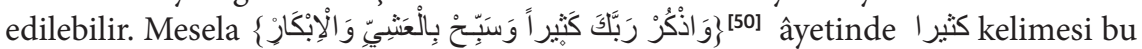

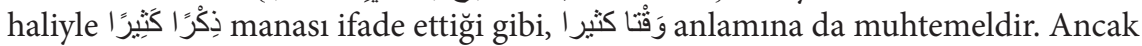

[46] Mefulün mutlaka nâib olan öğelere dair ayrıntılı bilgi için bkz. İbn Ya'îş, Şerhu'l-mufassal, 1/110-113; el-Endelûsî, Irtişâf, 3/1353- 1359; Abdulhamid, Evdahu'l-mesâlik, 2/213-225; Hasan, en-Nahvu'l-vâfî, 2/214-218.

[47] Nûh 71/17.

[48] İbn Ya'îş, Şerhu'l-mufassal, 1/112.

[49] Bâbe'ir, Zâhiratu'n-niyâbe fi'l-'Arabiyye, 304.

[50] Âl-i İmrân 3/41. 
mastarın zikri durumunda bahsi geçen ikinci anlam ortadan kalkmaktadır. ${ }^{[51]}$

Mef'ûlün mutlaka fiilin kendi mastarına nâib olarak gelme sebepleri arasında;

- Mastarın eş anlamlısını, zamirini ya da ism-i failini kullanarak anlamda bir genişlik sağlamak,

- Bir ismi işareti veya mastarın meydana geliş türlerinden birini nâib olarak kullanmak suretiyle mastarın türüne işaret etmek,

- Mastarın aynı kökten türeyen bir başka mastarını kullanarak tek bir ifadeyle iki anlama delalet etmek,

- Mastarın sayısına, aletine, yapısına veya zamanına delalet etmek vb. amaçlar siralanabilir. ${ }^{[52]}$

\section{4- Zaman ve Mekân Zarfına Niyâbe}

Cümlede mef'ûlün fîh konumunda olan yani isnâdın gerçekleştiği yeri veya zamanı bildiren öğeler zarflardır. Ancak özü itibariyle zarf olmadığı halde bazı isimler yer aldıkları cümlede isnâdın gerçekleştiği zamana veya mekâna delalet ederler. Başka bir değişle bazı kelimeler zarflara nâib olurlar. Bu öğeler şunlardır:

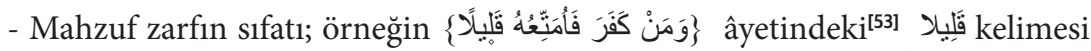
ş sَeklinde fiilin mastarına niyâbeten mef '̂ulün mutlak olarak alınması da dil açısından mümkündür. ${ }^{[54]}$ Burada şuna değinmek gerekir ki niyâbe konusunda kapsamlı bir çalışması olan modern araştırmacı Abdullah Salih, her ne surette olursa olsun bir sıfatın mevsufuna nâib olamayacağını iddia etmiş ve bunu uzun uzun delillendirmeye çalışmıştır. Ona göre buradaki durum sadece haziften ibarettir. ${ }^{[55]}$ Burada ayrıntıya girmemek üzere onun bu görüşüne katılmadığımızı ifade etmekle yetineceğiz. Zira söz gelimi ayetteki قليل kelimesi zarf özelliği taşımayan bir sıfattır. Ancak mevsufu mahzuf sıfat olarak değil, zarf olarak i'râb edilmektedir.

- Sayılar; örneğin عشريْرتُ عِشرين يوما cümlesinde عشرين sayısı zaman zarfina nâib olmuştur.

[51] Benzer örnekler için bakınız: es-Samerrâî, Me'âni'n-nahv, 2/164.

[52] Bâbe'ir, Zâhiratu'n-niyâbe fi'l-'Arabiyye, 295.

[53] el-Bakara 2/126.

[54] es-Samerrâî, Me'âni'n-nahv, 2/165.

[55] Bâbe'ir, Zâhiratu'n-niyâbe fi'l-'Arabiyye, 325. 
- İsm-i işaret; örneğin جئت هذا الوقت cümlesinde هذا kذا kelimesi bu türdendir.

بو gibi özü itibariyle zarf olmadıkları halde zarfa muzâf olan keli-

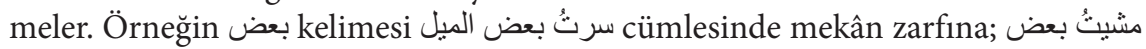
cümlesinde zaman zarfına nâib olmuştur.

- Mastarlar; zaman veya mekân zarflarının muzâfun ileyhleri olup, muzâfları hazfedildiği takdirde onlara nâib olarak gelebilirler. Mastarların zaman zarflarına nâib olarak kullanımları, mekân zarflarına nâib olmalarına nisbeten daha fazla-

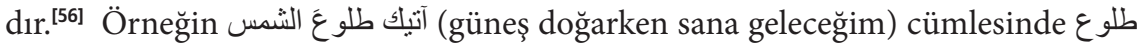
mastarı zaman zarfına; جلست قربَ زيد فلرع (Zeydîn yakınına oturdum) cümlesinde de قرب kelimesi mekân zarfına nâib olarak mef '̂̂lün fih konumunda gelmişlerdir. İlk

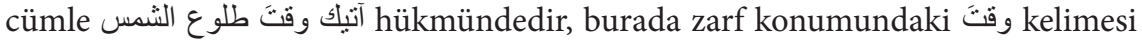
hazfedilip ona niyâbeten muzâfun ileyhi olan طلوع طلوع mastarı zarfiyyet konumunda mansup olmuştur. Zaman zarfı olarak bu şekilde kullanım tüm mastarlar için mümkün olmakla birlikte aynı şey mekân zarfı olarak kullanımda söz konusu değildir. Çünkü mastarların mekân zarfı olarak kullanımı nadirdir. Örneğin Zeyd'in oturduğu mekânı kastederek آتيك جلوسن زيد denmez, yaygın kullanım bu cümlenin onun oturma zamanını ifade ettiği yönündedir. ${ }^{[57]}$ Şunu da söylemek gerekir ki mastarlara dair bu söylenenler sarih mastarlar içindir, أنْ li mastarlar yani mastarı müevveller zarflara nâib olmazlar. ${ }^{[58]}$

Bunların dışında cümlede zımni bir في manasını içermesi sebebiyle zarfa

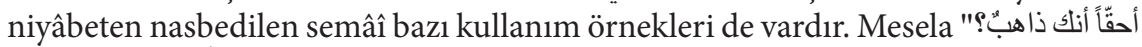
cümlesindeki حقّاً kelimesi aslında أفي حَقّ manasında kullanıldığ1 için bu kelime zarfiyyete niyâbeten mef '̂ulün fih olarak mansup yapılmıştır. ${ }^{\text {[59] }}$

Cümlelere doğru anlamlar yüklemede nelerin zarflara nâib olabileceği hususu önem arz etmektedir. Örneğin الدرسُ خروج الرجال şeklinde basit bir isim cümlesi ele alındığında bu cümlede خروج kelimesi müfred haber kabul edildiğinde "Ders adamların çıkmasıdır” şeklinde anlaşılacaktır. Ancak buradaki خروج kelimesinin bir mastar oluşu ve mastarların zarflara nâib olarak kullanılabilecekleri bilgisi göz önünde bulundurulduğunda bu cümle "Ders adamların çıktığı zaman olacaktır" şeklinde daha düzgün bir anlam ifade edecektir. İlk durumda خروج mastarı müfred haber konumunda olduğundan merfû; ikinci durumda ise zarfiyyet konumuna niyâbeten mansup yapılacak ve şibih cümle olarak mahallen merfû olacakır. Ancak denildiği gibi ikinci anlama ulaşabilmek için niyâbeye dair verilen malumatın bi-

[56] es-Suyûtî, Hem'u'l-hevâmi', 2/125.

[57] Bahauddin Abdullah el-'Akîîi el-Mısrî el-Hemedânî ibn Akîl, Şerh-u Ibn Âkîl 'alâ Elfiyyeti ibn Mâlik (Kahire: Dâru't-Turâs, 1980), 2/200.

[58] es-Suyûtî, Hem'u'l-hevâmi', 2/126.

[59] Said b. Muhammed b. Ahmed el-Afgânî, el-Mûcez fîk kavâ'idi'l-luğati'l-'Arabiyye (Beyrut: Dâru'l-Fikr, 2003), 286. 
linmesi gerekmektedir. Bu durumu niyâbe konusunun önemini ortaya koyan basit bir örnektir.

\section{5- Muzâfun İleyhin Muzâfa Nâib Olması}

Arap dilinde muzâf konumundaki öğenin hazfedilip muzâfun ileyhin onun yerini alması ve onun i'râbıyla i'rablanması oldukça yaygın bir kullanımdır. Kur'ân-1

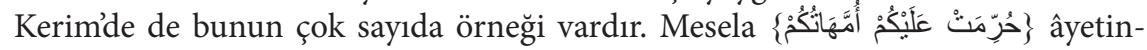

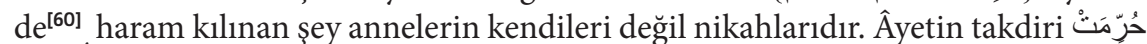

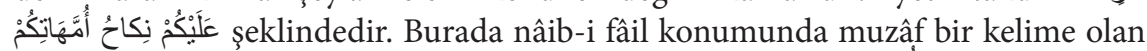

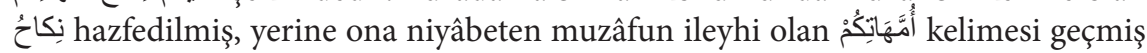
ve onun i'rabını alarak merfû olmuştur. Aynı şekilde نَكاحُ kelimesi için müzekker sigada gelmesi gereken fiil, o hazfolup muzâfun ileyhi yerini alınca, uyum gereği

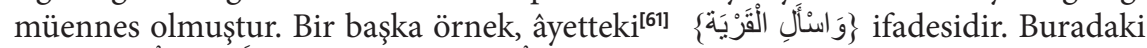

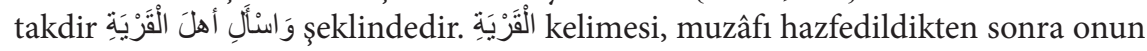
yerini almıştır.

Burada şöyle bir soru akla gelebilir. Muzâfın hazfedilip muzâfun ileyhin onun yerini alması her zaman mümkün müdür yoksa belli şartlara mı bağlıdır? Tabi ki bu soruya verilecek cevap hayırdır. Muzâf olan öğenin hazfi belirli şartlara bağlıdır.

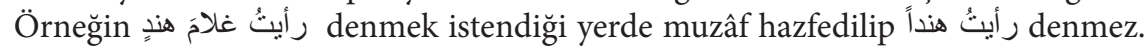

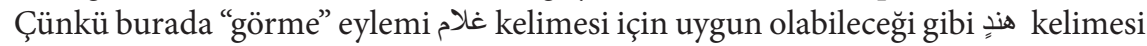
için de mümkündür. Dolayısıyla bu tarz bir niyâbe anlam karmaşasına yol açacaktır. ${ }^{[62]} \mathrm{Bu}$ sebeple muzâfın hazfedilip muzâfun ileyhin onun yerine geçmesi ancak kelamda bir karışıklığa sebebiyet verecek bir durumun olmadığı zaman mümkündür ki bu da hazif sonrası kalan kısmın muzâfın hazfedildiğine dair bir alamet taşıması halinde mümkündür.

Hazfedildiğine dair bir delilin olması durumunda muzâfın hazfedilip muzâfun ileyhin onun yerini almasının icâz- ihtisâr ve gereksiz yere sözü uzatmamak gibi pek çok sebebi vardır. Kelamda bir anlam genişliği sağlamak da bu sebepler

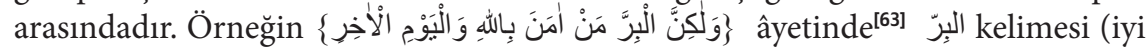
davranış) mastar olduğu için bir şahıs ile açıklanamaz. Halbuki âyette bu kelimeyi açıklayan haber şahıslara delaletle sَ şeklinde gelmiştir. Bu karineden yola çıkarak dilciler âyeti و لكنَّ البرَّ برُّ مَن آمن بالله duğunu söylemişlerdir. ${ }^{[64]}$ Ancak bu takdir kelamdaki anlam genişliğini ve mübalağayı ortadan kaldırmaktadır. Zira bu haliyle kelam müşahhaslaştırma yapmakta,

[60] en-Nisâ 4/23.

[61] Yûsuf 12/81.

[62] İbn Ya'îş, Şerhu'l-mufassal, 2/193.

[63] el-Bakara 2/177.

[64] Ebû Bişr Amr b. Osman b. Kanber el-Harisi es-Sîbeveyhi, el-Kitâb (Kahire: Mektebetü'l-Hânci, 1982), 1/282. 
eğer iyilik ete kemiğe bürünseydi Allah’a ve ahirete iman ederdi gibi bir anlam ifade etmektedir. Bu anlam genişlemesi muzâfın varlığ 1 durumunda söz konusu olmamakta, onun hazfi ile ortaya çıkmaktadır. ${ }^{[65]}$

\section{6- Mastarın Fiiline Nâib Olması}

Bazı durumlarda fiil zorunlu bir şekilde bazen de tercihe dayalı olarak hazfedilir ve mastarı onun yerini alır. Örneğin اضُربْ زَيدا ضَرْبَ cümlesi fiilin hazfedilip hazif öncesi mef ûülün mutlak konumundaki mastarının ona nâib olmasıly

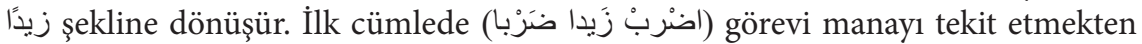
ibaret olan olan mastar, fiile nâib olunca bu görevinden soyutlanacak ve yeni görevler üstlenecektir. Çünkü nâib, menûb 'anhin konumunu üstlenir, onun delalet ettiğine delalet eder ve onun görevini yapar. Dolayısılyla cümle ضَرَبًْا زيدًا dönüştüğünde زَيدا kelimesinin âmili artık mahzuf fiil değil onun yerini alan mastardır. ${ }^{[6]]}$ Mastar bu şekilde fiiline nâib olunca delalet bakımından da onun özelliklerini üstlenecektir ki bunlar emre delalet, gelecek zamana delalet, ve fâile yani muhataba delalettir. İlk cümlede tekide delalet eden mastar ikincisinde emre yani fiilin gerçekleştirilmesi isteğine delalet etmektedir. Abdullah Salih bu tarz niyâbedeki amacın mübalağa olduğunu iddia eder. Ona göre ilk cümle fiil ile başlar ve bu fiil hem olaya (hades), hem zamana doğrudan delalet eder. Ancak mastar bu ikisinden hadesi ön plana çıkararak zihnin ona yoğunlaşmasını sağlar. ${ }^{[67]}$

\section{7- I'râb Alametlerinde Niyâbe}

Dilcilerin çoğunluğuna göre i'rabda asıl olan harekedir. ${ }^{[68]}$ İsimler damme ile merfû, fetha ile mansup ve kesra ile mecrur olurlar. Ancak başka bir hareke ile ya da harf ile i'râb edilen isimler de vardır. Şöyle ki merfû konumda olduğu zaman damme yerine tesniye kelimeler elif ile, esmâ-i hamse ve cemi müzeker sâlim kelimeler vâv ile merfû yapılır. Mansup konumda fetha dışında bir şeyle írâb edilen isimleri írâb alametleri; tesniye ve cemi müzekker sâlimlerde yâ harfi, cemi müennes kelimelerde kesra, esmâi hamsede elif harfidir. Mecrur isimlerde kesra ile írâb dışında tesniye, cemi müzekker sâlim ve esmâi hamsenin yâ ile, gayr-1 munsarif kelimelerin ise fetha ile i'râb edildikleri görülmektedir. Muzâri fiillerde ise ref alâmeti dammeye ek olarak nûn harfinin sübutu, nasb ve cezm halinde nûn harfinin veya illet harfinin hazfi asıldan farklı birer i'râb alameti olarak karşımıza çıkmaktadır.

Burada konumuzla ilgili sorular şunlardır. İ́râb alametleri asıl olarak yalnızca

[65] es-Samerrâî, Me'âni'n-nahv, 3/123.

[66] İbn Akîl, Şerh-u ibn Âkîl, 2/176.

[67] Bâbe'ir, Zâhiratu'n-niyâbe fi'l-'Arabiyye, 501.

[68] Ez-Zeccâcî, el-îzâh fî 'ileli'n-nahv, 72; Radıyyüddin Necmeddin Muhammed b. Hasan Radi el-Esterabadi, Şerhu'r-Radî 'ale'l-Kâfiye (Bingazi: Câmi'atü Kâri Yûnus, 1996), 1/74; es-Sabban, Hâşiyetu's-Sabbân, 1/87. 
harekeler midir yoksa harfler de harekeler gibi birer írâb alameti midir? Mansup ya da mecrûr konumdaki kelimelerin sırasıly damme, fetha ve kesra harekeler dışında başka bir hareke veya harf ile írâb edilmesi niyâbe kapsamında mıdır değil midir?

İ'râbın harf ile mi yoksa hareke ile mi olduğu konusu Basralı ve Kûfeli dilcilere göre farklılık arz eder. Basralılara göre írâbda asıl olan hareke ile olmasıdır. I'râb harekesinin verildiği bu harfi Sîbeveyhi írâb harfi şeklinde isimlendirir. ${ }^{[69]}$ Örneğin هذا جعرُ dendiğinde i'râb dammedir, írâb harfi de bu dammeyi taşıyan râ harfidir. Basralı dilcilere göre eğer írâb harf ile olacak olsaydı harfin de tıpkı bir hareke gibi başka bir harfe verilebilmesi/eklenebilmesi gerekirdi. Bu mümkün olmadığı için írâb hareke iledir. Kûfelilere göre ise i'râb hareke ile de harf ile de olabilir. Harf ile olduğu durumlarda bu harf kendi başına kâimdir, yani Basralıların írâb harfi dedikleri son harfin ardından gelen ve ondan bağımsız olan bir harftir. ${ }^{[70]}$

İ'rabda harekelerin asıl, harflerin onlara nâib olduğunu باب في إنابة الحركة عندة (harflerin harekelere, harekelerin harflere nâib olması hakkında) şeklinde ${ }^{[7]]}$ attığı başlık altında ele alan İbn Cinnî harflerin harekelere nâib olmasının tesniye elifi, cemaat vâvı ve esmâi sittede gerçekleştiğini belirtmektedir. Esmâi sittede elif, vâv ve yâ harflerinin sırasıyla fetha damme ve kesraya nâib olmasını írâbda onlarla aynı görevi yerine getirmeleriyle gerekçelendirmektedir. Tesniye, cemi müzekker sâlim ve muzari fiilde de aynı durumun olduğunu söyledikten sonra írâbdaki konumun aslında harekelere ait olduğunu ancak buralarda harflerin harekelere nâib olarak geldiklerini vurgulamaktadır. ${ }^{[2]}$

Görüldüğü gibi yukarıdaki sorulara cevap verebilmek için aslında tesniye, cemi müzekker sâlim, cemî müennes sâlim, esma-i hamse ve muzari fiilin durumlarını ayrı ayrı ele almak gerekir. Zira ismi geçen her bir tür için farklı yorumlarla karşlaşmak mümkündür. Ama genel itibariyle şunu söyleyebiliriz ki dilciler arasında yaygın olan görüşe göre merfû için damme, mansup için fetha, mecrur içinse kesra asıl írâb alameti olarak kabul edilmiş, bunlardan farklı olarak gelen írâb alametleri furû́ addedilmiş ve kelimenin fer' bir alametle i'râb edilmesi asla niyâbe olarak açıklanmıştır. Ezherî (ö. 905/1499) bu durumu şöyle özetlemektedir: 'Bilindiği üzere ref, nasb, ver ve cezm olmak üzere dört tür írâb vardır. Bunların alametleri ise ref için damme, nasb için fetha, cer (hafd) için kesra ve cezm için harekenin hazfidir. Bunlar aslî alametlerdir. Bir de asli alametlere nâib olan ferî alametler vardır ki bunlar da on tanedir. Üçü dammeye nâibdir ki bunlar elif, vâv ve nûn harfleridir. Fethaya nâib olan dört şey vardır. Bunlar kesra, elif, yâ ve nûn harfinin

[69] es-Sîbeveyhi, el-Kitâb, 1/13.

[70] Ez-Zeccâcî, el-îzâh fî́ 'ileli'n-nahv, 82.

[71] Ebu'l-feth Osman Ibn Cinnî, el-Hasâis (Mısır: Dâru'l-Kütübi'l-Mısriyye, t.y.), 3/133.

[72] İbn Cinnî, el-Hasâis, 3/135. 
hazfidir. Kesraya nâib olan iki şey vardır. Bunlar fetha ve yâ harfidir. Harekenin hazfine nâib olan ise tek bir şey vardır ki o da illet harfinin veya nûn harfinin hazfidir.' ${ }^{[73]}$

İrâb alametlerinin asıllığg ve füruluğu ile ilgili dilciler arasında yaygın görüş yukarıda zikredildiği gibi (harekeler asıl, diğerleri füru) olmakla birlikte ${ }^{[74]}$ özellikle modern dilciler bu konu üzerinde farklı görüşler de ortaya atmışlardır. Bu görüşlerden bazıları şu şekildedir:

Dr. Ahmed Alemuddin el-Cündî, i'râb alametlerinin harekelerden ibaret olduğunu belirtmiş, harflerin bu harekelere nâib olması hususunu reddetmiştir. Ancak buna makul bir alternatif getiremeyerek bazı kelimelerin i'râbsız bırakıldığ sonucuna varmıştır. Bu görüşe göre esmâi sittenin írâbı, meddi ile birlikte harekeyledir. Cemi müzekker sâlimdeki damme ref ve isnâd alameti, vâv ise işbấ içindir. Aynı şekilde kesra cer ve izafe alametidir ardından gelen yâ harfi de işbấ içindir. Nasb halinde ise cemi müzekker sâlim kelimelere normalde fetha ile elif eklenmesi gerekir, ancak eklendiğinde tesniyeye benzeyecektir. Bu sebeple bu forma nasb alameti verilmemiş mansup olması gerektiği durumda mecrûr form kullanılmıştır. Aynı şekilde merfû konumda bulunan tesniyenin sonundaki elif bir i'râb alameti değildir. Zira ref alameti yalnızca dammedir. Oradaki elif tesniye elifinden ibarettir. Kelimenin sonu dammelenmek istendiğinde elif ortadan kalkacaktır ki bu durumda tesniye manası da olmayacaktır. Bu sebeple bu görüşte tesniye formu da alametsiz bırakılmıştır. ${ }^{[75]}$

Modern araştırmacilardan Dr. Muhammed Hamâse Abdullatif'e göre bütün i'râb alametleri asıldır. Bulunduğu bir kelimede damme ne kadar asli bir i'râb alameti ise vâv harfi de bulunduğu kelimede onun kadar asli bir i'râb alametidir. Bu görüşe göre i'râb alameti ile i'râb durumu farklı şeylerdir. İ'râb durumu kelimenin cümledeki konumuna göre sabittir ancak örneğin موسى kelimesi gibi hiçbir i'râb alameti taşımayan kelimeler vardır. Bu tip kelimelerin takdiri de olsa bir i'râb alameti yoktur. Böyle bir takdire ihtiyaç da yoktur. Zira kelimenin anlamını belirleyen takdir edilen i'râb alameti değil írâb durumudur. ${ }^{\text {[6] }}$

Dr. Abdullah Salih'e göre ise i'râb alâmetleri yalnızca harekelerdir. Zahiri veya takdiri bir şekilde damme ref'; fetha nasb; kesra cer ve harekenin hazfi de cezm alametidir. İ'râbda asıl olan bunlardır. Bunlara aykırı olarak gelen i'râb alâmetleri

[73] Ebü't-Velid Zeynüddin Halid b. Abdullah b. Ebu Bekr Vakkad Ezheri, Şerhu't-tasrîh 'ale't-tavzîh (Beyrut: Dâru'l-Kütübi'l-'Ilmiyye, 2000), 1/57.

[74] Abdulhamid, Evdahu'l-mesâlik, 1/64.

[75] Ahmed Alemuddin el-Cündî, “Fi'l-i'râbi ve müşkilâtih”, Mecelletü Mecme'i'l'-Luğati'l-'Arabiyye 42 (1978), 171172.

[76] Muhammed Hamâse Abdullatif, El-'Alâmetü'l-i'râbiyye fi'l-cümle beyne'l-kadîm ve'l-hadîs (Kuveyt: Matbûâtu Camiati Kuveyt, 1984), 157. 
(gayr-1 munsarifin fethayla mecrur olması gibi) ise asla niyâbeten değil, bir ses olayına veya bir nahiv illetine bağlı olarak asıldan yapılan değişiklikten ibarettir. ${ }^{[7]}$ Ona göre esmâi sittenin írâb edildiği elif aslında fethanın uzun halidir, başka bir deyişle fetha aslında elifin bir cüz üdür. Vâv ve yâ harfleri de aynı şekilde damme ve kesraya karşılık gelir. Dolayısıyla bunlarda bir asıl-nâib söz konusu değildir. ${ }^{[78]}$ Tesniye ve cemi müzekker sâlimde kelimenin sonuna eklenen elif, vâv ve yâ harfleri i'râb alameti değil yalnızca tesniye ve cemiyi temsil eden formlardır. Bu formların írâb alameti olmak gibi bir görevleri yoktur. Dolayısıyla bu kelimelerin i'râbı kelimenin asil harflerinin sonuncusuna takdir edilen fetha, damme veya kesra iledir. Írâbın takdiri olma sebebi ise telaffuz illetine bağlıdır. ${ }^{[79]}$ Ona göre cemi müennes sâlimin fetha yerine kesra ile mansup olmasında ve gayr-1 munsarif kelimelerin kesra yerine fetha ile mansup olmasında da niyâbe söz konusu değildir. Cemi müennes kelime için ses olaylarından dolayı kesra asıl olarak nasb alametidir, gayr-1 munsarif kelimeler için de fetha asıl olarak bir cer alametidir. Bundaki illet de fiillere benzememektir. ${ }^{[80]}$

Görüldüğü üzere i'râb alametlerine dair klasikten farklı olarak modern dönemde ortaya atılan görüşlerin hiç birisi írâb alâmetleri arasında niyâbeyi kabul etmemektedir. Bunların her birisi çalışmalarında görüşlerini uzun uzadıya delillendirmeye çalışmışlardır. Bu tartışmalara burada ayrıntılarıyla girmek istemiyoruz. Ancak kısaca değinmek gerekirse kelimelerin írâbsız bırakıldığı görüş makul bir görüş değildir. Zira isimlerde asıl olan mu'rab olmaktır. Aynı cümle içerisine giren iki isimden birisinin írâbını kabul ederken bir başkasını sırf yapısı farklı diye i'râbsız diye nitelemek doğru değildir.

Abdullah Salih'in elif, vâv ve yâ harflerini fetha damme ve kesranın uzun halleri kabul edip bunları esmâi sittenin írâb alametleri olarak ileri sürmesi makul kabul edilebilir. Ancak cemi müennes sâlimin ses olaylarına bağlı olarak kesra ile mansup olmasından yola çıkarak bu tür kelimeler için kesrayı asıl olarak bir nasb alameti iddiası tutarlı değildir. Zira kesra asıl olarak cer alametidir. Aynı zamanda nasb alâmeti olarak kabul edilmesi cemi müennes sâlim kelimelerle benzer ses özeliklerine sahip diğer kelimeler için de bir írâb alameti olmasını gerektirir ki böyle bir durum söz konusu değildir. Diğer taraftan cemi müzekker sâlimin nasb halinin ve tesniyenin ref halinin son harfine takdir edilen bir damme veya fetha ile gerçekleşmesi makul değildir. Zira zaten harekesi olan mu'râb bir isme hareke takdir edilmez. Onun bu sonuca varmasına yol açan şey niyâbeyi yalnızca nahvî terkiplerde var olan bir olgu olarak kabul etmesi, bunun dışında harf ve hareke düzeyinde niyâbeyi reddetme çabasının bir sonucudur. Nitekim bu durum, yaptığ 1

\footnotetext{
[77] Bâbe'ir, Zâhiratu'n-niyâbe fi'l-'Arabiyye, 177.

[78] Bâbe'ir, Zâhiratu'n-niyâbe fi'l-'Arabiyye, 179.

[79] Bâbe'ir, Zâhiratu'n-niyâbe fi'l-'Arabiyye, 186.

[80] Bâbe'ir, Zâhiratu'n-niyâbe fi'l-'Arabiyye, 191.
} 
niyâbe tanımında da kendini göstermektedir. Bu sebeple o, i'râb alametlerinin birbiri yerine kullanılmasını nahvi terkipten bağımsız olarak kelime özelinde gerçekleşen hususlar olması gerekçesiyle niyâbe olarak kabul etmemiştir.

\section{8- Cümlelerin Müfred Kelimelere Nâib Olması}

Nahivcilerin çoğunluğuna göre Arapçada isim cümlesi ve fiil cümlesi olmak üzere iki tür cümle vardır. Cümlenin türünü belirlemedeki kriter onun ilk kelimesidir. Eğer isimle başlıyorsa bir cümle isim cümlesi, fiil ile başlıyorsa da fiil cümlesidir. Bu kriterden yola çıkan bazı dilciler zarf ya da câr mecrûrla başlayan cümleleri (فى الدَّار زيد cümlesi gibi) ayrı bir tür olarak değerlendirmişlerdir. Bazı dilciler de cümleyi isim, fiil ve şart cümleleri şeklinde üçe ayırıp şart cümlesini ayrı bir tür kabul etmişlerdir. Cümleyi sadece isim cümlesi ve fiil cümlesi şeklinde taksim edenler ise bu son iki türü isim ya da fiil cümlesi içerisinde değerlendirmişlerdir. [81] Hangi taksim kabul edilirse edilsin her durumda cümle müsned-müsned ileyh olmak üzere asgari iki bileşenden oluşmaktadır. Diğer taraftan cümlelerde asıl olan bağımsız, kendi başına kaim olmaktır. Cümlelerin müfred öğelere nâib olması tam da bu noktada ortaya çıkmaktadır.

İ'râb olgusu asıl itibariyle müfred öğeler (isim veya muzari fiil) içindir. Zira müfred öğe, i'râb harekesini zahiri bir şekilde alabilen veya takdiri olarak taşıyabilen tek bir kelimeden ibarettir. Cümle ise, en az iki kelimeden oluştuğu için írâb harekesi alabilmesi söz konusu değildir. İ'râbın, asıl itibariyle, yalnızca müfred öğeler için olması bu sebepledir. ${ }^{[82]}$ Müfred öğeler, içerisinde yer aldıkları cümledeki konumlarına göre i'râb edilir, bu konumun gerektirdiği i'râb alametini kendi yapılarına uygun olarak taşırlar. Cümlelerde ise Ebû Hayyân’ın ifadesiyle asıl olan müstakil olmaktır. ${ }^{[83]}$ Başka bir deyişle asıl olan cümlelerin i'râbda bir mahallinin bulunmamasıdır. Ancak bazı cümlelerin írâbda mahallinin olduğu da bir gerçektir. Bu durumu dilciler cümlenin müfredin yerini alması başka bir deyişle cümlenin müfrede nâib olması şeklinde açıklamışlardır. Örneğin İbn Cinnî bu hususta "müfred ile cümle arasında benzerlikler vardır, cümlenin sıfat, haber veya hal olarak müfredin yerini alması bunlardandır. Mesela مررتُ برجل وجهُه حسن (Yüzü güzel olan bir adama uğradım) cümlesinde وجهُه حسن (onun yüzü güzeldir) cümlesi bir sıfat konumunda müfredin yerini almıştır, ${ }^{[84]}$ demektedir. Şunu özellikle vurgulamak gerekir ki bir cümlenin müfrede nâib olması demek oradaki cümlenin yerine bir müfred öğe takdir edip anlamı ona göre vermek demek değildir. Müfrede nâib olan cümlenin müfrede te’vil edilmesi mümkündür, ancak bu te’vil bir zorunluluk

[81] Bu konudaki farklı görüşler için bkz. İbn Ya'îş, Şerhu'l-mufassal, 1/88; es-Suyûtî, Hem'u'l-hevâmi', 1/57; Fahreddin Kabâve, I'râbü'l-cümel ve eşbâhü'l-cümel (Haleb: Dârü'l-Kalemi'l-Arabi,, 1989), 19-25.

[82] Kabâve, I'râbü'l-cümel ve eşbâhü'l-cümel, 33.

[83] el-Endelûsî, İrtişâf, 3/1617.

[84] İbn Cinnî, el-Hasâis, 3/181. 
değildir. Radî, (ö. 688/1289'dan sonra) 'bir cümlenin müfrede nâib olması' ifadesinin, írâb açısından onun müfred için mümkün olan bir konumda bulunmasından ve mahalli olarak onun írâbını almasından öte bir şey olmadığını belirtir. ${ }^{[85]}$ Zira müfrede tevil edilmesi durumunda bir cümlenin anlam özellikleri bakımından değişikliğe uğraması pek çok durumda kaçınılmaz bir sonuçtur.

Buradan yola çıkarak cümleleri müfredin yerini alan yani ona nâib olabilen cümleler ve müfrede nâib olmayan cümleler şeklinde iki kısma ayırmak mümkündür. Aslında bu taksim ilgili kitaplarda daha meşhur haliyle írâbda mahalli olan cümleler ve írâbda mahalli olmayan cümleler şeklinde yer bulmuştur. Bu açıdan írâbda mahalli olan cümle, yerine müfred bir öğenin takdir edilebildiği cümleye tekabül ederken, írâbda mahalli olmayan cümle de bu takdirin yapılamadığı türe karşıllk gelmektedir ${ }^{[86]}$ Cümleleri írâbda mahallinin olup olmamasına göre taksim etmedeki amaç içerisinde yer aldığ kelamdaki konumunun net olarak belirlenmesi, öncesi ve sonrası ile bağlantısının ortaya konmasıdır. Bu amacın dışında cümle her iki durumda da aynı cümledir, özellikleri bakımından farklllık göstermez. ${ }^{[87] Y a n i ~ a y n ı ~ s ̦ e k i l d e ~ k u r u l m u s ̧ ~ b i r ~ c u ̈ m l e n i n ~ i c ̧ e r i s i n d e ~ y e r ~ a l d ı g ̆ ı ~ k o n u m a ~ g o ̈ r e ~ i ́ r a ̂ b-~}$ da mahalli olabileceği gibi bazen de olmaz. Ancak eğer müfrede nâib bir konumda ise içeriğiyle veya lafzıyla ona delalet edecek ve mahalli veya takdiri olarak onun i'râbını alacaktır.

$\mathrm{Bu}$ yönüyle cümleler aslında bazı müfred öğelere benzerler. Örneğin harflerin, mazi ve emir fiillerin írâbda mahalli yoktur, ancak bu durum onların öncesiyle veya sonrasıyla alakasının olmadığı, içerisinde yer aldığı bağlamdan tamamen soyutlandığı anlamına gelmez. Buradaki mebnilikten kasıt bağlamının veya etrafındaki kelimelerin değişmesiyle anlamının değişmeyeceği ve her durumda sabit olan tek bir formunun olmasıdır. İsimlerin ve múrab fiillerin sonları ise bağlamına, öncesinde ve sonrasında bulunan diğer öğelerle lafzi veya manevi bağlantısına dayalı olarak değişir. Cümlelerin durumu da tıpkı müfredlerinki gibidir. Írâbda mahalli olmayan cümleler, mebni kelimelere benzerken i'râbda mahalli olanlar da mu'rab kelimelere benzerler, lafızlarının veya içeriklerinin delaletiyle onların yerini alırlar. Ancak tıpkı mebni ve müfred múrablarda olduğu gibi cümlelerin her iki türünün de öncesi ve sonrasıyla bir alakası ve yer aldığı kelamda bir görevi vardır. ${ }^{[88]}$

Cümlelerin kendisine nâib olduğu müfred öğe, mastar ya da ism-i fâil, ismî mef ûl, sıfat-1 müşebbehe gibi bir müştak isim olabilir. ${ }^{[89]}$ Örneğin

[85] el-Esterabadi, Şerhu'r-Radî 'ale'l-Kâfiye, 4/103,243.

[86] es-Suyûtî, Hem'u'l-hevâmi', 2/331.

[87] Kabâve, írâbü'l-cümel ve eşbâhü'-cümel, 35.

[88] Kabâve, I'râbü'l-cümel ve eşbâhü'l-cümel, 36.

[89] Bâbe'ir, Zâhiratu'n-niyâbe fi'l-'Arabiyye, 572. 


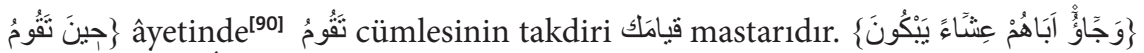
âyetinde ${ }^{[91]}$ يَيْكُونَ cümlesinin takdiri بـاكِين şeklinde ism-i fâildir. Üçüncü bir tür olarak cümlelerin meczum konumdaki muzari fiile nâib olabileceği de iddia edilmiştir. Onlara göre bu durum şart cümlelerinde cevap cümlesinin fâ ile başladığ 1 durumlarda vardir. ${ }^{[92]}$

Müfrede nâib olup onun írâbını alan cümlelerin sayısı hakkında farklı görüşler ileri sürülmüştür. Çoğunluğun görüşüne göre bunlar yedi tane olup aşağıdaki cümlelerdir:

- Haber konumundaki cümle: Mübtedânın veya inne ve kardeşlerinden birinin haberi konumundaki cümle mahallen merfû, kane ve kardeşlerinin haberi konumundaki cümle mahallen mansuptur. عليٌّ جاء صنديقُه cümlesinin haberi bu şekildedir.

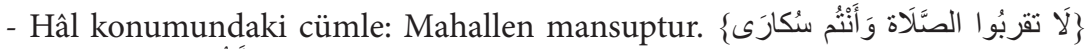
âyetinde ${ }^{[93]}$ وَأَنُُُْ سكارى cümlesi buna örnektir.

- Mef 'ûl konumundaki cümle: قول veya türevi bir fiille hikaye edilen ve fâile

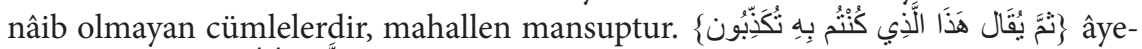

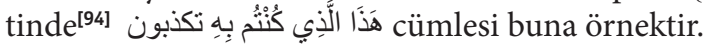

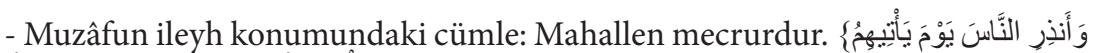

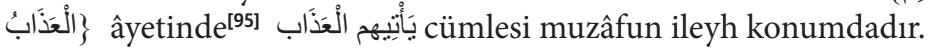

- Cezmeden bir şart cümlesinin cevabinda fâ harfinden veya إذ dan (fucâiyye) sonra gelen cümle: muzari fiile niyabeten mahallen meczum konumdadır.

- Müfrede tabi olan cümle: Sıfat, atıf harfi ile atıf, ya da bedel olmak üzere üç

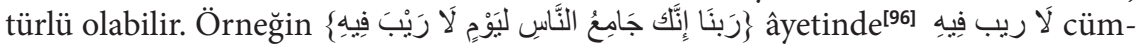

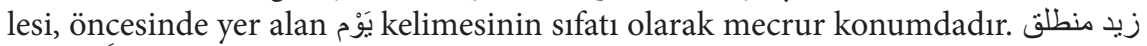

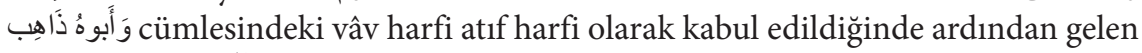
cümle habere (منطلق) atfedilmiş olup mahallen merfû konumda olmaktadır.

- İ'râbda mahalli olan bir cümleye tâbi olan cümle: Bu durum atf-1 nesakda

[90] et-Tûr 52/48.

[91] Yûsuf 12/16.

[92] Kabâve, I'râbü'l-cümel ve eşbâhü'l-cümel, 136.

[93] en-Nisâ 4/43.

[94] el-Mutaffifîn 83/17.

[95] Ibrahim 14/44.

[96] ̂̂l-i İmrân 3/9. 
ve bedelde olmaktadır. örneğin زيد قَامَ أَبوهُ وَقَعد أَخُوهُ cümlesinde vâv harfi atıf olarak kabul edildiğinde وَقَعد أَخُوهُ cümlesi نَامَ أَبوهُ cülesine atıfla mahallen merfû olmaktadir. ${ }^{[97]}$

Burada nâib öğenin írabına da değinmek gerekirse bu konuda nâibi faili diğerlerinden ayrı tutmak gerekir. Zira nâib-i fâil, fâil olarak i’rab edilmez. Ancak diğer niyâbe örneklerinde nâib öğe işgal ettiği konuma göre i’rab edilir. Mesela bir mastara niyâbeten mef' ûlün mutlak konumunda olan bir ism-i tafdil veya ism-i alete doğrudan mef 'ûlün mutlak denir. Aynı şekilde mahzuf muzâfına nâib bir muzâfun ileyh, işgal ettiği konuma göre doğrudan fâil, mef 'ûl, mübteda, haber vb. şeklinde i'rab edilir.

\section{SONUÇ}

Niyâbe, bir sebebe bağlı olarak bir cümlenin veya bir terkibin unsurlarından birisinin hazfedilip onun yerine başka bir öğenin geçmesi ve bu yeni öğenin, işgal ettiği makamın bir gereği olarak mahzufun bazı özelliklerini taşıması şeklinde özetlenebilir. İlk dönem dil kitaplarında bu olgu 'bir şeyin başka bir şeyin yerine geçmesi' manasına sahip pek çok tabirle ifade edilmiş, ancak zamanla bu ifade tarzının kapsamına giren bedel, ta'vîz gibi benzer dil olgularından ayrışarak niyâbe şeklinde kavramlaşmıştır. Niyâbe, fâilin hazfedilip mef 'ûlün onun yerine geçmesi, bir muzâfın hazfedilip yerini muzâfun ileyhine bırakması veya bir fiile kendi mastarı dışında bir şeyin mef'ûlün mutlak olarak bağlanması gibi cümlede bir öğenin hazfedilip yerini başka öğelere bırakması şeklinde karşımıza çıktığı gibi írâb alametleri düzeyinde de gerçekleşebilmektedir. Hangi türden olursa olsun niyâbe mutlaka bir sebebe binaen ortaya çıkmaktadır. Bu sebep, gramatik açıdan dilin temel kurallarına aykırılık oluşturan bir problemin çözümü gibi dilin genel kaide ve kurallarına ya da îcâz, ihtisâr ve manada genişlik sağlamak gibi terkip ve cümlelerin delâlet ettikleri manaya yönelik olabilmektedir. Arap dilinde tarihi süreçte pek çok tartışmaya ve ihtilafa konu olmuş oldukça kapsamlı bir örneklemi bulunan niyâbe olgusunu tüm örneklemiyle bir makaleye sı̆̆dırmak mümkün değildir. Ancak bu örneklemden kullanım sıklığına göre yapılan bir seçkiyle niyâbenin genel çerçevesi çizilmeye çalışılmıştır.

[97] I'râbda mahalli olan cümlelerin sayıları, türleri ve dilcilerin bunlara dair ihtilafları hakkında ayrıntılı bilgi için bkz. Ebû Muhammed Cemaleddin Abdullah b. Yusuf ibn Hişam, Muğni'l-lebîb 'an kütübi'l-e'ârîb (Dimaşk: Dâru'l-Fikr, 1985), 536-557; Kabâve, I'râbü'l-cümel ve eşbâhü'l-cümel, 135-270; Bâbe'ir, Zâhiratu'n-niyâbe fi'l-'Arabiyye, 574-595. 


\section{KAYNAKÇA}

Abdulhamid, Muhammed Muhyeddin. Evdahu'l-mesâlik ilâ Elfiyyeti Ibn Mâlik. Beyrut: Menşûrâtu'l-Mektebeti'lAsriyye, t.y.

Abdullatif, Muhammed Hamâse. El-'Alâmetü'l-i'râbiyye fi'l-cümle beyne'l-kadîm ve'l-hadîs. Kuveyt: Matbûâtu Camiati Kuveyt, 1984.

Bâbe‘ir, Abdullah Salih Amr. Zâhiratu’n-Niyâbe fi'l-'Arabiyye. Yemen: Dâru Hadramevt, 2010.

el-Afgânî, Said b. Muhammed b. Ahmed. el-Mûcez fî kavâ‘idi'l-luğati'l-'Arabiyye. Beyrut: Dâru'l-Fikr, 2003.

el-Cündî, Ahmed Alemuddin. "Fi'l-i'râbi ve müşkilâtih”. Mecelletü Mecme'i'l-Luğati'l-'Arabiyye 42 (1978): 155-172.

el-Enbârî, Ebû'l-Berekât (ö. 577). Esrâru'l-'Arabiyye. Kuveyt: Vuzâretu'l-Evkâf ve’ş-Şuûni'l-Islâmiyye, 2015.

el-Endelûsî, Ebu Hayyân. İrtişâfu'd-darb min Lisâni'l-Arab. Kahire: Matbaatu'l-Hânci, 1998.

el-Esterabadi, Radıyyüddin Necmeddin Muhammed b. Hasan Radi Şerhu'r-Radî 'ale’l-Kâfiye. Bingazi: Câmi‘atü Kâri Yûnus, 1996.

Ezheri, Ebü'l-Velid Zeynüddin Halid b. Abdullah b. Ebu Bekr Vakkad. Şerhu't-tasrîh 'ale't-tavzîh. Beyrut: Dâru'lKütübi'l-'Ilmiyye, 2000.

Hasan, Abbas. en-Nahvu'l-vâfî. Kahire: Dâru'l-Meârif.

Ibn Akîl, Bahauddin Abdullah el-'Akîlî el-Mısrî el-Hemedânî. Şerh-u Ibn Âkîl 'alâ Elfiyyeti Ibn Mâlik. Kahire: Dâru'tTurâs, 1980.

Ibn Cinnî, Ebu'l-feth Osman. el-Hasâis. Mısır: Dâru'l-Kütübi'l-Mısriyye, t.y.

İbn Fâris, Ebü'l-Hüseyn Ahmed b. Fâris b. Zekeriyyâ. es-Sâhibî fî fikhi'l-luğa ve süneni'l-'Arab fî kelâmihâ. Beyrut: Dâru'l-Kütübi'l-'Ilmiyye, 1997.

Ibn Hişam, Ebû Muhammed Cemaleddin Abdullah b. Yusuf Muğni'l-lebîb 'an kütübi'l-e’ârî̉b. Dimaşk: Dâru'l-Fikr, 1985.

İbn Malik et-Tâî, Ebû Abdullah Cemaleddin Muhammed b. Abdullah Şerhu’t-teshîl. Gîze: Hicr, 1990.

Ibn Manzûr, Muhammmed b. Mukrim Ebu'l-Fâzıl. Lisânu'l-'Arab. Beyrut: Dâru Sâdir, 1993.

Ibnü's-Serrac, Ebû Bekr Muhammed b. Seri b. Sehl el-Bağdadi el-Usûl fi'n-nahv. Beyrut: Müessesetü’r-Risâle, t.y. Ibn Ya'îş, Ali b. Ya'îş, Muvaffakuddin Ya'iş b. Ali. Şerhu'l-mufassal. Mısır: Idâretü’t-Tıbâ’ati’l-Münîriyye, t.y.

Kabâve, Fahreddin. I‘râbü’l-cümel ve eşbâhü’l-cümel. Haleb: Dârü’l-Kalemi’l-Arabi, 1989.

el-Lubdî, Muhammed Semîr Necib. Mu'cemu'l-mustalehâti'n-nahviyye ve's-sarfiyye. Beyrut: Muessesetu'r-Risâle, 1985.

el-Müberred, Ebu'l-Abbâs Muhammed b. Yezîd. el-Muktedab. Kahire: Lecnetü ihyâ-i Türâsi'l-İslâmi, $1994 .$.

es-Sabban, Ebü'l-İ́fan Muhammed b. Ali. Hâşiyetu's-Sabbân ‘alâ Şerhi'l-Üşmûnî lielfiyyeti Ibni Mâlik. Beyrut: Dâru'l-Kütübi'l-'Illmiyye, 1997.

es-Samerrâî, Fazı Salih. Me'âni’n-nahv. Kahire: Şeriketu'l-'Atik li Sınâ‘ati’l-Kitâb, 2003.

es-Sîbeveyhi, Ebû Bişr Amr b. Osman b. Kanber el-Harisi el-Kitâb. Kahire: Mektebetü'l-Hânci, 1982.

es-Suyûtî, Celâleddin Abdurrahman b. Ebî Bekr. el-iktirâh fî usûli'n-nahv. Dimaşk: Dâru'l-Beyrûtî, 2006.

es-Suyûtî, Celâleddin Abdurrahman b. Ebî Bekr. Hem'u'l-hevâmi' fî şerh-i cem'i-l'cevâmî'. Beyrut: Daru'l-Kütübi'lIlmiyye, 1998.

eş-Şemâyile, Eymen Mubarek Ramazan. En-Niyâbetu fi'n-nahvi'l-Arabî. Yüksek Lisans Tezi, Ürdün Üniversitesi, Lisansüstü Çalışmalar Enstitüsü, 2011.

eş-Şemrî, Mecid Nevd. "en-Niyâbe vemâ yudâri'uhâ minel'l-mustalehâti'n-nahviyye”. Mecelletü'l-Feth 2/27 (2006): 22-29.

el-Ukberî, Ebu'l-Bekâ Abdullah b. Huseyn. el-Lübâb fî 'ileli'l-binâ ve'l-iłrâb. Beyrut: Dârü'l-Fikri'l-Muâsır, 1995

ez-Zebîdî, Ebü'l-Feyz Muhammed Murtaza el-Huseynî. Tâcü'l-'arûs min cevâhiri'l-kâmûs. Kuveyt: Matba‘atu Hukûmeti'l-Kuveyt, 1977.

Ez-Zeccâcî, Ebu'l-Kâsım Abdurrahman b. İshak. el-Îzâh fî 'ileli’n-nahv. Beyrut: Dâru’n-Nefâis, 1979.

ez-Zerkeşî, Imâm Bedreddin Muhammed b. Abdillah. el-Burhân fî 'ulûmi'l-Kur'ân. Kahire: Mektebetü Dari't-Turâs, 1984. 